25. Потернак Ю.П. Податковий контроль у системі забезпечення економічної безпеки держави. Науковий вісник Львівського державного університету внутрішніх справ. серія економічна. 2013. Вип. 1. C. $105-112$.

26. Романенко В.В. Негативні фактори економічної безпеки держави у контексті податкового ризик-менеджменту. Вісник Академіі митної служби України. Серія : Економіка. 2014. № 2. С. 112-119.

27. Чиж В.I. Податкове адміністрування як спосіб забезпечення економічної безпеки регіону. Економіка та право. Серія : Економіка. 2016. № 2. C. 46-52.

DOI https://doi.org/10.30525/978-9934-26-040-7-38

\title{
ГРОМАДЯНСТВО, ПАТРІОТИЗМ ТА ПРИСЯГА ПУБЛІЧНИХ СЛУЖБОВЦІВ: МОДЕЛІ ПОСДНАННЯ У СЛУЖБОВОМУ ПРАВІ КРАЇН СВІТУ
}

\author{
Коломоєць Т. О. \\ доктор юридичних наук, професор, \\ заслужений юрист України, \\ член-кореспондент Начіональної академії правових наук Украӥни, \\ декан юридичного факультету \\ Запорізького національного університету
}

Кремова Д. С. здобувач третього рівня вищої освіти кафедри адміністративного та господарського права Запорізького національного університету м. Запоріжжя, Украӥна

Аналіз положень службового права різних країн світу дозволяє із упевненістю стверджувати, що нерозривний зв'язок «громадянства публічного службовця» як обов'язкової (спеціальної) умови вступу особи на службу, «патріотизму» як одного із засадничих принципів служби і службового права в цілому й Присяги публічного службовця як певного політико-правового факту, що засвідчує «початок» відданих відносин особи під час служіння публічним інтересам. Цей 
«понятійний» ряд $\epsilon$ цілком логічним, бо «фокусується» на «зв'язку» особи, яка перебуває на публічній службі, зорієнтованості іiі на відданість публічним інтересам, відданість народу та його інтересам, відданість державі та іiі інтересам, із народом та державою. Такий «зв'язок» не може бути договірним, контрактним, умовним або ж іншим (за умови дотримання будь-яких варіацій), не може бути й другорядним, додатковим, похідним. Його «засадничість» зумовлює пріоритетність уваги до наявності у особи публічного службовця громадянства країни, на посаді публічного службовця у якій особа перебуває (або ж претендує на зайняття), фіксацію як принципу служби такої особи патріотизму (можливими $є$ різні зовнішні форми виразу його, із використанням словосполучень, в т.ч. й уточнюючого змісту) $\mathrm{i}$ Присяги публічного службовця на вірність службі публічним інтересам народу. Саме такий «зв'язок» й зумовлює поєднання «... віри у майбутнє свого народу, готовність до праці на користь народу, знання та вміння осмислювати його моральні та культурні цінності, звичаї, символіку ... готовність ідентифікувати себе 3 громадянами своєї держави та потребу у самоствердженні $з$ метою власного духовного й інтелектуального зростання» [1, с. $41 ; 2$, с. 40], а отже й перспективність результативного виконання завдань публічної служби.

Тим не менш, з огляду на специфіку самої публічної служби, розмаїття зовнішніх форм організаційно-правового ії прояву, можна підтвердити й розмаїття моделей такого поєднання громадянства, патріотизму як принципу і Присяги публічного службовця як політико-правового факту, що фіналізує процедуру прийняття (вступу) на публічну службу у службовому праві різних країн і щодо різновидів публічної служби.

Так, «жорсткою» можна вважати модель обов'язкової триелементної «зв'язки» зазначених інституцій, а саме: обов'язкове громадянство публічних службовців, нормативне закріплення патріотизму як засадничого принципу у службовому законодавстві (або єдиному систематизованому нормативно-правовому акті про публічну службу або ж у законодавчих актах про різновиди публічної служби), а також Присяги публічного службовця як стадії процедури прийняття (вступу) на публічну службу. Вона $\epsilon$ характерною для більшості країн пострадянського простору та країн Європи. Наприклад, Закон України «Про державну службу» закріплює всі три інституції як обов'язкові, Закон Іспанії «Про цивільних службовців держави» фіксує аналогічні положення.

Водночас для деяких країн світу характерною є й т. зв. «м'яка» модель зв'язку зазначених інститутів службового права і це зумовлене 
особливістю як виду публічної служби, так і посади такої служби. Зокрема, у Швеції наявність громадянства є обов'язковим лише для певних посад в урядових установах, для решти ж питання визначається безпосередньо у законодавстві про різновид публічної служби. При цьому інші два інститути також унормовані в залежності від різновиду служби. «М'якою» цілком можна вважати і модель «зв'язку», передбачену у службовому праві Австралії. Хоча громадянство, а отже i патріотизм, і прийняття Присяги для сфери публічної служби в Австралії є обов'язковими, втім до «фінальної стадії прийняття на публічну службу, до прийняття Присяги допускається практика участі у конкурсі на заміщення вакантної посади публічної служби й навіть проходження випробувального строку особами, які не мають громадянства країни, втім виявили бажання його отримати й ініціювати відповідну процедуру. У службовому законодавстві Австралії безпосередньо й передбачено можливість «дотичності» особи до сфери публічної служби «до надання особі австралійського громадянства» [3, с. 111]. Хоча саме із набуттям такого громадянства особа набуває статусу публічного службовця, а отже на ії діяльність поширюється дія принципу патріотизму й для остаточного набуття вищезазначеного статусу важливим $\epsilon$ проходження процедури прийняття Присяги службовця, водночас все ж таки певне «послаблення» імперативу триелементного зв'язку для сфери публічної служби, а отже і для службового права $є$. Саме тому австралійська модель відповідного зв'язку є «м'якою». Ще більш ліберальною виглядає й американська модель, яка не зважаючи на імператив триелементного зв'язку «громадянство - патріотизм - Присяга», як загальний вектор регулювання публічно-службових відносин, передбачає й певне «резервування» посад у Державному департаменті саме для іноземних громадян. Не для тих, хто бажає змінити, або ж додатково тримати громадянство США, саме для іноземних громадян. I в даному немає імперативу щодо обов'язковості «прив'язки» до Присяги та патріотизму. Отже, американську модель також цілком логічно вважати «м'якою».

Детальний аналіз навіть вищезазначених моделей дозволяє і у їх межах виокремити окремі різновиди. Так, наприклад, у «жорсткій» моделі зв'язку «громадянство - патріотизм - Присяга», яка є характерною, як вже зазначалося, для країн пострадянського простору та більшості країн Східної Свропи, можна виокремити і «м'який» підвид, притаманний врегулюванню відносин патронатної служби. Для останньої важливим $\epsilon$ «зв'язок» особи із «патроном», а отже, громадянство не $\epsilon$ імперативом, як і не $\epsilon$ імперативом прийняття Присяги такими особами. Це, свого роду, «служба здобичи» як вид моделі публічної 156 
служби в цілому, саме тому імператив обов'язково триелементного зв'язку не $\epsilon$ характерним для службового права навіть країн загальної «жорсткої» моделі для відносин патронатної служби [4, с. 123]. Однак, якщо для патронатної служби «м'який» підвид зв'язку може бути і це $\epsilon$ цілком логічним, для різновидів державної служби (як мілітаризованої, так й цивільної, як для внутрішньої, так і для зовнішньої) такий варіант регламентації відносин взагалі є неприйнятним і це варто врахувати в умовах обгрунтування доцільності систематизації службового законодавства й закріплення у єдиному нормативно-правовому акті про публічну службу положень про громадянство як умову вступу на державну (у всіх різновидах), муніципальну, військову, альтернативну службу, про патріотизм як засадничий принцип відповідної служби та обов'язкове фіналізування процедури вступу на службу у вигляді прийняття Присяги публічними службовцями. «М'яка» модель може поширюватися на дотичні (консультативні, допоміжні, дорадчі, вторинні тощо) різновиди служби, а отже для них цілком логічно (в окремому розділі систематизованого службового нормативно-правового акту) передбачити положення, які б не містили імперативу щодо наявності не лише зв'язку, а й самих таких елементів.

\section{Література:}

1. Науково-практичний коментар до Закону України «Про державну службу» / наук. ред.: акад. А.О. Селіванов, акад. М.І. Іншин. К.: Парлам. вид-во, 2017. 512 с.

2. Бех І.Д. Національна ідея в становленні громадянина - патріота України (програмно-виховний контекст). К.: ІПВ АПН України, 2008. $40 \mathrm{c}$.

3. Административное право зарубежных стран: учебник / Под ред. А.Н. Козырина, М.А. Штатиной. М.: Спарк, 2003. 464 с.

4. Коломоєць Т.О. Адміністративне право України. Академічний курс : підручник. К.: Юрінком Інтер, 2011. 576 с. 